\title{
EFEKTIFITAS PENERAPAN MODEL PEMBELAJARAN KOOPERATIF TIPE NUMBERED HEADS TOGETHER (NHT) TERHADAP PRESTASI BELAJAR EKONOMI SISWA KELAS X SMA A. WAHID HASYIM GADINGMANGU PERAK TAHUN 2012/2013
}

\author{
Mohammad Imron Rosyadi \\ Guru SMA A. Wahid Hasyim Gadingmangu Perak
}

\begin{abstract}
Abstrak: Penelitian ini bertujuan untuk menjelaskan: (1) prestasi belajar ekonomi siswa kelas X SMAN Bandarkedungmulyo tahun 2011/2012 dengan diterapkan model pembelajaran kooperatif tipe Numbered Heads Together (NHT) dalam pembelajarannya, (2) prestasi belajar ekonomi siswa kelas X SMAN Bandarkedungmulyo tahun 2011/2012 tanpa diterapkan model pembelajaran kooperatif tipe Numbered Heads Together (NHT) dalam pembelajarannya, (3) efektifitas penerapan model pembelajaran kooperatif tipe Numbered Heads Together (NHT) terhadap prestasi belajar Ekonomi siswa kelas X SMAN Bandarkedungmulyo tahun 2011/2012. Penelitian ini termasuk penelitian eksperimen. Populasi penelitian ini adalah siswa kelas X SMAN Bandarkedungmulyo tahun 2011/2012, yang terbagi dalam 6 kelas. Pengambilan sampel dilakukan dengan teknik random sampling kelas, diperoleh X-1 sebagai kelas eksperimen dan X-3 sebagai kelas kontrol. Metode pengumpulan data yang digunakan yaitu tes, observasi, wawancara, dan dokumentasi. Teknik analisis data menggunakan uji t (uji beda) dua sampel berpasangan dengan pengolahan datanya menggunakan SPSS 17.00 for Windows. Hasil penelitian menunjukkan mean prestasi belajar kelas eksperimen 79,23 dan mean prestasi belajar kelas kontrol 67,70. Selain itu, juga diperoleh nilai probabilitas $(\mathrm{p})<\operatorname{taraf}$ signifikan $(\alpha)$ yang ditetapkan dan thitung $>$ t-tabel, dengan keterangan angka $0,00<0,05$ dan $6.95>2,042$. Maka Hipotesis nol (Ho) ditolak dan Hipotesis alternatif(Ha) diterima.
\end{abstract}

Kata Kunci: Numbered Heads Together (NHT), Prestasi Belajar Ekonomi.

\section{PENDAHULUAN}

Sekolah sebagai lembaga yang menyelenggarakan pendidikan formal, memiliki peranan yang sangat penting dalam mewujudkan tujuan pendidikan nasional melalui proses pembelajaran. Pendidikan mempunyai fungsi dan tujuan yang harus diperhatikan sesuai pada UURI No. 20 Tahun 2003 Tentang Sistem Pendidikan Nasional Pasal 3 menyatakan bahwa: pendidikan nasional berfungsi mengembangkan kemampuan dan membentuk watak serta peradaban bangsa yang bermartabat dalam rangka mencerdaskan kehidupan bangsa, bertujuan untuk berkembangnya potensi siswa agar menjadi manusia yang beriman dan bertakwa kepada Tuhan Yang Maha Esa, berakhlak mulia, sehat, berilmu, cakap, kreatif, mandiri dan menjadi warga negara yang demokratis serta bertanggung jawab (Undang-Undang Sisdiknas, 2003: 5-6).

Dengan adanya Undang-Undang tersebut, maka dari waktu ke waktu bidang pendidikan haruslah tetap menjadi prioritas untuk selalu ditingkatkan mutunya dengan berbagai cara. Seperti peningkatan mutu para guru, pembaharuan kurikulum dan penambahan berbagai fasilitas belajar. Tercapainya tujuan pendidikan nasional dapat dilihat dari sebagian prestasi belajar yang diperoleh 
siswa. Keberhasilan itu pada umumnya dikaitkan dengan tinggi rendahnya nilai yang dicapai oleh siswa, daya serap siswa, serta prestasi siswa yang berupa nilai hasil raport. Kenyataan menunjukkan bahwa disamping adanya siswa yang berhasil secara gemilang, masih juga terdapat siswa yang memperoleh prestasi belajar yang kurang menggembirakan, bahkan ada diantara mereka yang tidak naik kelas atau tidak lulus pada Ujian Nasional(UNAS).

Udin Winataputra mengartikan model pembelajaran sebagai kerangka konseptual yang melukiskan prosedur yang sistematik dalam mengorganisasikan pengalaman belajar untuk mencapai tujuan belajar tertentu dan berfungsi sebagai pedoman bagi perancang pengajaran dan para guru dalam merencanakan dan melaksanakan aktifitas belajar mengajar (http://wyw1d.wordpress. com/2009/10/12/model-pembelajaran/).

Dalam model pembelajaran secara konvensional ini juga lebih didominasi peran serta oleh siswa-siswa tertentu saja. Dimana siswa yang aktif dalam pembelajaran cenderung lebih aktif dalam bertanya dan menggali informasi dari guru maupun sumber belajar yang lain sehingga cenderung memiliki pencapaian prestasi belajar yang lebih tinggi. Siswa yang kurang aktif cenderung pasif dalam pembelajaran, mereka hanya menerima pengetahuan yang datang padanya sehingga memiliki pencapaian prestasi belajar yang lebih rendah.

Oleh karena itu, perlu dikembangkan suatu model pembelajaran yang mampu melibatkan peran serta siswa secara menyeluruh sehingga proses pembelajaran tidak hanya didominasi oleh siswa-siswa tertentu saja. Selain itu, melalui pemilihan model pembelajaran tersebut diharapkan sumber informasi yang diterima siswa tidak hanya dari guru melainkan juga dapat dari sesama teman atau yang lainnya, dan juga diharapkan mampu meningkatkan peran serta dan keaktifan siswa dalam mempelajari dan menelaah ilmu yang ada. Bahkan, banyak penelitian menunjukkan bahwa pengajaran oleh rekan sebaya (peerteaching) ternyata lebih efektif dari pada pengajaran oleh guru (Lie, 2007: 12).

Model pembelajaran yang lebih mengutamakan pada keaktifan siswa dalam proses pembelajaran dan juga melatih keterampilan sosial adalah model pembelajaran kooperatif, yaitu model pembelajaran dimana siswa bekerjasama dan saling membantu dalam kelompok kecil yang heterogen untuk mencapai tujuan dan penghargaan yang sama. "Pembelajaran kooperatif unggul membantu siswa dalam menumbuhkan kemampuan bekerja sama, berfikir kritis dan kemampuan membantu teman" (Nur, dkk: 2005b: 12). Model pembelajaran kooperatif diharapkan mencapai tiga tujuan pembelajaran antara lain: (1) hasil belajar akademik, (2) penerimaan terhadap keragaman, (3) pengembangan keterampilan sosial (dalam Susilowibowo, 2009: 148). Oleh karena itu, bisa dikatakan model pembelajaran kooperatif (cooperative learning) merupakan pendekatan dalam proses pembelajaran yang berbasis kelompok.

Salah satu model pembelajaran kooperatif yaitu tipe NHT (Numbered Heads Together). Model ini dapat dijadikan alternatif variasi model pembelajaran sebelumnya. Dibentuk kelompok heterogen, setiap kelompok beranggotakan 3-5 siswa, setiap anggota memiliki satu nomor, guru mengajukan pertanyaan untuk didiskusikan bersama dalam kelompok. Guru menunjuk salah satu nomor untuk mewakili kelompoknya. Menurut Muhammad Nur (2005) model pembelajaran kooperatif tipe NHT (Numbered Heads Together) pada dasarnya merupakan sebuah variasi diskusi kelompok dengan ciri khasnya adalah guru hanya menunjuk seorang siswa yang mewakili kelompoknya tanpa memberitahu terlebih dahulu siapa yang akan mewakili kelompoknya tersebut. Sehingga cara ini menjamin keterlibatan total semua siswa. Cara ini upaya yang sangat baik untuk meningkatkan 
tanggung jawab individual dalam diskusi kelompok (http://www.papantulisku. com/2010/01/ model-pembelajaran-kepalabernomor_15.html).

\section{Efektifitas Penerapan Model Pembe-} lajaran Kooperatif Tipe Numbered Heads Together (NHT) Terhadap Prestasi Belajar Ekonomi

Model pembelajaran kooperatif (cooperative learning) bernaung di bawah pembelajaran konstruktivistik yang muncul dari konsep bahwa siswa akan lebih mudah menemukan dan memahami konsep yang sulit jika mereka berdiskusi dengan temannya. Siswa secara rutin bekerja dalam kelompok untuk saling membantu memecahkan masalah-masalah yang kompleks. Hakikat dari pembelajaran kooperatif ini adalah penggunaan kelompok sejawab dalam proses pembelajaran (Suhardiyanto, 2009: 71). Slavina (dalam Rusman, 2011: 201) mengatakan pembelajaran kooperatif menggalakkan siswa berinteraksi secara aktif dan positif dalam kelompok. Ini membolehkan pertukaran ide dan pemeriksaan ide sendiri dalam suasana yang tidak terancam, sesuai dengan falsafah konstruktivisme.

Berbagai kelebihan dalam pembelajaran kooperatif tipe Numbered Heads Together (NHT), seperti setiap siswa menjadi siap semua, dapat melakukan diskusi dengan sungguh-sungguh, siswa yang pandai dapat mengajari siswa yang kurang pandai, dapat mengubah struktur kelas tradisional, seperti mengacungkan tangan terlebih dahulu sebelum ditunjuk guru untuk menjawab pertanyaan yang dilontarkan. Suasana seperti ini menimbulkan kegaduhan dalam kelas, karena para siswa saling berebut dalam mendapatkan kesempatan untuk menjawab pertanyaan guru.

Selain itu, model ini memberi kesempatan kepada siswa untuk saling membagikan ide-ide dan mempertimbangkan jawaban yang paling tepat. Serta mampu mendorong siswa untuk meningkatkan semangat kerjasama mereka. Model ini bisa digunakan dalam semua mata pelajaran dan untuk semua tingkatan usia anak didik (Lie, 2007: 59).

Hal ini sudah terbukti pada hasil penelitian yang telah dilakukan para peneliti terdahulu yang telah diuraikan diatas, yang pada intinya memang ada efektifitas dalam penerapan model pembelajaran kooperatif tipe Numbered Heads Together (NHT) pada proses pembelajaran yang dilakukan oleh guru, ditunjukkan dengan meningkatnya aktivitas, motivasi belajar dan prestasi belajar siswa yang sangat baik.

\section{METODOLOGI PENELITIAN}

Peneliti membagi sasaran penelitian menjadi dua kelas, yaitu kelas eksperimen dan kelas kontrol. Kelas eksperimen adalah kelas yang diberi perlakuan/dengan diterapkan model pembelajaran kooperatif tipe Numbered Heads Together (NHT) dalam pembelajarannya. Kelas kontrol adalah kelas yang tidak diberi perlakuan / tanpa diterapkan model pembelajaran kooperatif tipe Numbered Heads Together (NHT) dalam pembelajarannya. Oleh karena itu, penelitian eksperimen ini termasuk kategori True Eksperiment Design.

\section{Populasi dan Sampel}

Tabel 3.2. Populasi Siswa Kelas X SMAA. Wahid Hasyim Gadingmangu Perak Tahun 2012/2013

\begin{tabular}{|c|c|c|}
\hline No. & Kelas & $\begin{array}{c}\text { Jumlah } \\
\text { Siswa }\end{array}$ \\
\hline 1. & X-1 & 34 \\
\hline 2. & X-2 & 36 \\
\hline 3. & X-3 & 34 \\
\hline 4. & X-4 & 34 \\
\hline 5. & X-5 & 34 \\
\hline 6. & X-6 & 36 \\
\hline & Total Siswa & $\mathbf{2 0 8}$ \\
\hline
\end{tabular}

Sumber : bagian Tata Usaha SMA A. Wahid Hasyim Gadingmangu Perak Tahun 2012/2013. 
Tabel 3.3. Sampel Siswa Kelas X SMAN Bandarkedungmulyo

\begin{tabular}{|c|c|c|c|}
\hline Kelas & $\begin{array}{c}\text { Laki } \\
\text {-laki }\end{array}$ & Perempuan & Jumlah \\
\hline X-1 & 14 & 20 & 34 \\
\hline X-3 & 14 & 20 & 34 \\
\hline
\end{tabular}

Sumber : bagian Tata Usaha SMA A. Wahid Hasyim Gadingmangu Perak Tahun 2012/2013.

\section{Teknik Analisis Data}

Teknik analisis data yang digunakan adalah uji t (uji beda) dua sampel berpasangan untuk menjelaskan ada tidaknya efektifitas penerapan model pembelajaran kooperatif tipe Numbered Heads Together (NHT) terhadap prestasi belajar ekonomi siswa kelas $\mathrm{X}$ SMA A. Wahid Hasyim Gadingmangu Perak Tahun 2012/2013.

Analisis statistik tersebut dengan taraf signifikasi 0,05 dan derajat kebebasan $(\mathrm{df})=$ $\mathrm{N}-1$. Adapun persamaan dalam penelitian ini sebagai berikut:

1. untuk menghitung mean masing-masing kelompok

$$
\begin{aligned}
& M_{1}=\frac{\sum X_{1}}{N_{1}} \\
& M_{2}=\frac{\sum X_{2}}{N_{2}}
\end{aligned}
$$

2. untuk menghitung nilai thitung

$$
t=\frac{M_{1}-M_{2}}{\sqrt{\left\{\frac{\sum X_{1}^{2}+\sum X_{2}^{2}}{\left(n_{1}-1\right)+\left(n_{2}-1\right)}\right\}\left\{\frac{1}{n_{1}}+\frac{1}{n_{2}}\right\}}}
$$

(Arikunto: 2006, 3011)

Dimana

$\mathrm{T}$ : harga(koefisien) thitung

$\mathrm{M}_{1}$ : rata-rata (mean) kelompok eksperimen

$\mathrm{M}_{2}$ : rata-rata (mean) kelompok kontrol

$\mathrm{X}_{1}$ : deviasi skor siswa kelompok eksperimen

$$
\begin{aligned}
& \mathrm{X}_{2}: \text { deviasi skor siswa kelompok } \\
& \text { kontrol } \\
& \mathrm{n}_{1}: \begin{array}{l}
\text { jumlah responden kelompok ekspe- } \\
\text { rimen }
\end{array} \\
& \mathrm{n}_{2}: \begin{array}{l}
\text { jumlah responden kelompok } \\
\text { kontrol }
\end{array}
\end{aligned}
$$

\section{HASIL PENELITIAN DAN PEMBA- HASAN}

Inti dari analisis ini adalah output ketiga yang merupakan tabel Paired Samples Test. Pada tabel ini terlihat bahwa mean sebesar 11.52941 dengan standar deviasi sebesar 9.67654. Nilai t-hitung sebesar 6.947. Sedangkan nilai Sig (2-tailed) sebesar 0.000 $<0,05$ sehingga dapat disimpulkan bahwa $\mathrm{Ha}$ diterima, dan dapat dikatakan bahwa ada "Efektifitas Penerapan Model Pembelajaran Kooperatif Tipe Numbered Heads Together (NHT) Terhadap Prestasi Belajar Ekonomi Siswa Kelas X SMA A. Wahid Hasyim Gadingmangu Perak Tahun 2012/2013.

Setelah hasil data penelitian dianalisis dan memperoleh kesimpulan, langkah selanjutnya adalah melakukan interpretasi sebagai berikut:

a. Nilai tertinggi dari prestasi belajar siswa yang dengan diterapkan model pembelajaran kooperatif tipe Numbered Heads Together (NHT) adalah 91 dan nilai terendah adalah 63 . Sedang nilai tertinggi dari prestasi belajar siswa yang tanpa diterapkan model pembelajaran kooperatif tipe Numbered Heads Together (NHT) adalah 85 dan nilai terendah adalah 54.

b. Hasil analisis statistik dengan menggunakan aplikasi program SPSS 17.00 for Windows dengan metode paired sample T-tes didapat nilai Mean prestasi belajar dengan diterapkan model pembelajaran kooperatif tipe Numbered Heads Together (NHT) sebesar 79.2353 = 79,23 dan Mean prestasi belajar tanpa diterapkan model pembelajaran kooperatif tipe Numbered Heads Together (NHT) sebesar 67.7059= 67,70. Sehingga selisih dari rata-rata 
keduanya adalah 11,53 . Sementara nilai thitung didapat sebesar $6.947=6.95$. Jika nilai ini dikonsultasikan pada daftar ttabel dengan taraf signifikan $(\alpha) 5 \%$ dan $\mathrm{df}=\mathrm{N}-1=33$ maka didapatkan t-tabel sebesar 2,042. Sehingga t-hitung (6.95) $>$ t-tabel (2,042). Selain itu dari hasil analisis dan statistik dengan menggunakan aplikasi program SPSS 17.00 for Windows juga didapatkan nilai probabilitas sebesar 0,00 karena nilai probabilitas $<$ taraf signifikan $(\alpha)$ yang ditetapkan dan t-hitung $>$ t-tabel, dengan keterangan angka $0,00<0,05$ dan $6.95>2,042$ maka Hipotesis nol (Ho) ditolak dan Hipotesis alternatif (Ha) diterima.

3. Pembahasan

Hipotesis alternatif (Ha) telah terbukti sehingga dapat pula dinyatakan bahwa ada "Efektifitas Penerapan Model Pembelajaran Kooperatif Tipe Numbered Heads Together (NHT) Terhadap Prestasi Belajar Ekonomi Siswa Kelas X SMA A. Wahid Hasyim Gadingmangu Perak Tahun 2012/ 2013 Tahun 2012/2013". Dengan kata lain bahwa upaya peningkatan prestasi belajar mata pelajaran ekonomi siswa kelas $\mathrm{X}$ di SMA A. Wahid Hasyim Gadingmangu Perak Tahun 2012/2013 dapat ditempuh melalui penerapan model pembelajaran kooperatif tipe Numbered Heads Together (NHT) sebagai alternatif pilihan dari berbagai model pembelajaran yang ada pada saat ini. Karena dengan penerapan model pembelajaran kooperatif tipe Numbered Heads Together (NHT) ini mampu meningkatkan prestasi belajar siswa. Hal ini terbukti pada saat penerapan model pembelajaran kooperatif tipe Numbered Heads Together (NHT) mata pelajaran ekonomi pada siswa kelas $\mathrm{X}$ (kelas eksperimen) menunjukkan peran serta dan keaktifan siswa selama proses pembelajaran yang sangat bagus. Selain itu memang terbukti mampu meningkatkan prestasi akademik, sebab siswa yang lebih mampu menjadi narasumber bagi siswa yang kurang mampu. Siswa juga mampu menerima teman-temannya yang mempunyai berbagai perbedaan latar belakang, baik perbedaan suku, agama, kemampuan akademik, dan tingkat sosial. Serta siswa juga mampu mengembangkan keterampilan sosialnya. Keterampilan sosial yang dimaksud seperti, berbagi tugas, aktif bertanya, menghargai pendapat orang lain, memancing teman untuk bertanya, mau menjelaskan ide atau pendapat, bekerja dalam kelompok dan sebagainya.

\section{PENUTUP \\ Simpulan}

Setelah dilakukan penelitian, deskripsi data, analisis data, interpretasi dan pembahasan, maka langka akhir dari suatu penelitian tersebut adalah pemberian simpulan dan yang dapat peneliti simpulkan sebagai berikut:

1. Ada "Efektifitas Penerapan Model Pembelajaran Kooperatif Tipe Numbered Heads Together (NHT) Terhadap Prestasi Belajar Ekonomi Siswa Kelas X SMA A. Wahid Hasyim Gadingmangu Perak Tahun 2012/2013 Tahun 2012/2013”. Hal ini dibuktikan dengan nilai probabilitas $(p)<$ taraf signifikan $(\alpha)$ yang ditetapkan dan t-hitung $>$ t-tabel, dengan keterangan angka $0,00<0,05$ dan $6.95>2,042$ maka Hipotesis nol (Ho) ditolak dan Hipotesis alternatif(Ha) diterima.

2. Nilai rata-rata prestasi belajar siswa yang dengan diterapkan model pembelajaran kooperatif tipe Numbered Heads Together (NHT) adalah 79,23. Sedangkan nilai rata-rata prestasi belajar siswa yang tanpa diterapkan model pembelajaran kooperatif tipe Numbered Heads Together (NHT) adalah 67,70. Sehingga selisih dari rata-rata keduanya adalah 11,53 . Hal ini menunjukkan bahwa proses pembelajaran dengan menerapkan model pembelajaran kooperatif tipe Numbered Heads Together 
(NHT) mempunyai tingkat efektifitas yang baik dalam meningkatkan prestasi belajar ekonomi siswa kelas X SMA A. Wahid Hasyim Gadingmangu Perak Tahun 2012/2013 Tahun 2012/2013.

3. Oleh karena itulah, memang perlu sekali dikembangkan suatu model pembelajaran dalam proses pembelajaran di kelas, yang pada prinsipnya pengembangan model pembelajaran bertujuan untuk menciptakan situasi pembelajaran yang efektif dan efisien, menyenangkan, bermakna, dan lebih banyak mengaktifkan siswa. Dimana salah satunya adalah model pembelajaran kooperatif tipe Numbered Heads Together (NHT) ini, tentunya juga disesuaikan dengan pokok bahasannya.

\section{Saran}

Adapun saran yang dapat peneliti sampaikan adalah:

1. Hendaknya guru memiliki keterampilan dan kemampuan yang cukup dalam memilih serta menerapkan model pembelajaran kooperatif tipe Numbered Heads Together (NHT) agar proses pembelajaran dapat berjalan dengan efektif.

2. Penerapan model pembelajaran kooperatif tipe Numbered Heads Together (NHT) harus memberikan kesempatan dan kebebasan pada semua siswa untuk menyampaikan pendapat mereka secara individu tanpa adanya paksaan. Sehingga proses diskusi ini dapat menumbuhkan keberanian siswa dalam mencurahkan pendapatnya dan memunculkan ide-ide kreatifmereka.

3. Pada saat proses pembelajaran tipe Numbered Heads Together (NHT) hendaknya guru selalu memantau jalannya proses pembelajaran, sehingga dapat mengevaluasi kegiatan diskusi dengan maksimal, selain itu dalam teknik penilaian terhadap siswa hendaknya tidak hanya dilakukan diakhir pembelajaran tetapi juga selama proses pembelajaran berlangsung.
4. Hendaknya bidang pendidikan terus menjadi prioritas untuk selalu ditingkatkan mutunya, baik melalui pelatihanpelatihan, seminar dan workshop mengenai dunia pendidikan termasuk dalam konteks perubahan paradigma dari berpusat pada guru (teacher centered) menjadi berpusat pada siswa (student centered). Selain itu, hendaknya guru tidak hanya sebagai "pengajar" yang hanya melakukan transfer of knowledge, akan tetapi juga sebagai "pendidik" yang melakukan transfer of values, dan sekaligus sebagai "pembimbing" yang memberikan pengarahan dan menuntun siswa dalam belajar. Bisa dikatakan, baik buruknya suatu bangsa dimasa mendatang banyak terletak ditangan guru.

\section{DAFTAR PUSTAKA}

Arikunto, Suharsimi. 2002. Prosedur Penelitian Suatu Pendekatan Praktek. Jakarta: Rineka Cipta.

Arikunto, Suharsimi. 2006. Prosedur Penelitian Suatu Pendekatan Praktek. Jakarta: Rineka Cipta.

Asra dan Sumiati. 2008. Metode Pembelajaran. Bandung: CV. Wahana Prima.

Depdiknas. 2004. Materi Pelatihan Terintegrasi Sains SN-38.

Fajar, Arnie. 2008. Portofolio dalam Pelajaran IPS. Bandung: PT. Remaja Rosdakarya.

Hamalik, Oemar. 2008. Perencanaan Pengajaran Berdasarkan Pendekatan Sistem. Jakarta: PT. Bumi Aksara.

Jihad, Asep dan Abdul Haris. 2007. Evaluasi Pembelajaran. Yogyakarta: Multi Pressindo.

Lie, Anita. 2007. Cooperative Learning. Jakarta: PT. Grasindo. 
Miarso, Yusufhadi. 2004. Menyemai Benih Teknologi Pendidikan. Jakarta: Pustekkom Diknas Bekerjasama dengan Kencana.

Mulyasa, E. 2007. Manajemen Berbasis Sekolah. Bandung: PT. Remaja Rosdakarya.

Musrofi, M. 2010. Melesatkan Prestasi Akademik Siswa. Yogyakarta: PT. Pustaka Insan Mandiri.

Nurhadi. 2004. Pembelajaran Kontekstual dan Penerapannya dalam KBK. Malang: Universitas Negeri Malang.

Purwanto, Ngalim. 2000. Psikologi Pendidikan. Bandung: PT. Remaja Rosdakarya.

Pusat Penelitian (PUSLIT) STKIP PGRI Jombang. 2009. Buku Pedoman Usulan Penelitian dan Penulisan Skripsi. PUSLIT STKIP PGRI Jombang. Jombang.

Riyanto, Yatim. 2010. Paradigma Baru Pembelajaran. Jakarta: Prenada Media Group.

Rosdiana dan Lambertus. 2006 . Meningkatkan Prestasi Belajar Matematika Siswa Kelas VIII Pada Pokok Bahasan Faktorisasi Suku Aljabar Melalui Pembelajaran Kooperatif Tipe NHT di SMP Negeri 15 Kendari. http://isjd.pdii.lipi.go.id/ admin/jurnal/142074954.pdf (03 Nopember 2011).

Rusman, 2011. Model-Model Pembelajaran. Jakarta: Rajawali Press.

Sardiman, A.M. 2009. Interaksi dan Motivasi Belajar Mengajar. Jakarta: PT. Raja Grafindo Persada.

Slameto. 2003. Belajar dan Faktor-Faktor yang Mempengaruhinya. Jakarta: PT. Rineka Cipta.

Sudjana, N. 2006. Penilaian Hasil Proses Belajar Mengajar. Bandung: PT. Remaja Rosdakarya.
Suhardiyanto, Andi. 2009. Peningkatan Kualitas Pendidikan Melalui Model Pembelajaran Kooperatif Berbasis Kontruktivistik. Lembaran Ilmu: Jilid 38 (1): 68-77. http://journal.unnes.ac.id (03 Nopember 2011).

Sukmara, Cucu. 2011. Pembelajaran Kooperatif NHT (Numbered Heads Together) dalam Upaya Meningkatkan Prestasi Belajar Matematika Siswa di SMP Negeri 1 Sukarame Kabupaten Tasikmalaya Jawa Barat. Jurnal Saung Guru: Volume 2(2): 15-23. http://lib.unnes.ac.id/1600/ (02 Nopember 2011).

Sumiati dan Asra. 2008. Metode Pembelajaran. Bandung: CV. Alfabeta.

Suprijono, Agus. 2009. Cooperative Learning. Yogyakarta: Pustaka Pelajar.

Susilowibowo, Joni dan Lika Yuliati. 2009. Penerapan Model Pembelajaran Kooperatif Tipe Kepala Bernomor Struktur Untuk Mencapai Ketuntasan Belajar. Jurnal Pendidikan Ekonomi: Volume 1(3): 147-158. http://jurnal. pdii.lipi.go.id/admin/jurnal/130914715 8.pdf(03 Nopember 2011).

Sutikno, Sobri., dkk. 2007. Strategi Belajar Mengajar. Bandung: PT. Rafika Aditama.

Syah, Muhibin. 2007. Psikologi Pendidikan. Bandung: PT. Remaja Rosdakarya.

Undang-Undang Sisdiknas 2003 (UU RI No. 20 Th. 2003). Jakarta: Sinar Grafika.

Uno, Hamzah. 2011. Teori Motivasi dan Pengukurannya. Jakarta: PT. Bumi Aksara.

Warsita, Bambang. 2008. Teknologi Pembelajaran. Jakarta: PT. Rineka Cipta.

(22 Oktober 2011).

http://www.papantulisku.com/2010/01/mode 1-pembelajaran-kepala-bernomor_15. html) (22 Oktober 2011) 
http://starawaji.wordpress.com/2009/05/01/p engertian-efektivitas/ (22 Oktober 2011).

http://akhmadsudrajat.wordpress.com/2008/ 09/12/pendekatan-strategi-metodeteknik-dan-model-pembelajaran/(22 Oktober 2011).

(02 Nopember 2011).

http://library.um.ac.id/free-contents/ index.php/ pub/detail/penerapan-model - pembelajaran-kooperatif-tipenumbered-heads-together-nht-untuk meningkatkan-aktivitas-motivasi-danprestasi-belajar-siswa-pada-matapelajaran-ekonomi-kelas-viii-b-mtssurya-buana-malang-wahyu-sriwidayati-36154.html (20 Oktober 2011).

http://lib.unnes.ac.id/3013/ (20 Oktober 2011).

http://ipotes.wordpress.com/2008/05/10/met ode-pembelajaran-kooperatif/ (20 Oktober 2011). 